\title{
Penguatan Modal Sosial Menuju Kemandirian Perempuan Perdesaan Pelaku Industri Rumahan Emping Melinjo di Provinsi Banten
}

\author{
(Strengtheining Social Capital to Wards Self Reliance Of Rural Women Of Home Industry \\ “emping Melinjo" In Banten Province
}

\author{
Khaerul Saleh ${ }^{1}$, Sumardjo ${ }^{2}$, Aida Vitayala S Hubeis ${ }^{2}$, dan Herien Puspitawati ${ }^{3}$ \\ ${ }^{1}$ Jurusan Agribisnis, Fakultas Pertanian, Universitas Sultan Ageng Tirtayasa, Serang \\ ${ }^{2}$ Departemen Sains Komunikasi dan Pengembangan Masyarakat, Fakultas Ekologi Manusia Institut Pertanian Bogor, Bogor \\ 3Departemen Ilmu Keluarga dan Konsumen, Fakultas Ekologi Manusia Institut Pertanian Bogor, Bogor
}

\begin{abstract}
The home industry has been lacking the ability to compete in the market due to the low level of knowledge, skill and capability to the mastery of technology and access to capital, whereas its existence has an important position in the national economy. This study aims to determine the role of micro and meso social capital and its problems to the independence of women in rural home industries emping melinjo. The study was conducted in Banten Province, with a sample of 453 people, consisting of; 154 people in industrial zones, 147 people in agricultural zones and 152 people in tourism zones of 6,857 rural women home industries emping melinjo. Data analysis used descriptive statistics, one way anova, and Structural Equation Modeling (SEM). The results of the analysis show that the level of independence, capacity level, social capital of meso and micro social capital of women in rural areas are in the medium category. The hybryd model shows that rural women's independence is 43.0 percent directly affected by meso social capital and capacity level, while micro-social capital is influenced through capacity-level work. The level of rural women's independence is determined through aspects of decision-making, cooperation, business dynamics and access to capital. Strategy for increasing self-reliance is done through strengthening of meso social capital, especially infrastructure support and extension materials, which has indirect influence on strengthening micro social capital and rural women's capacity level
\end{abstract}

Keywords: Home Industrial "emping melinjo", social capital micro, meso social capital, the level of capacity and autonomy of rural women

\begin{abstract}
Abstrak
Industri rumahan selama ini kurang memiliki kemampuan untuk bersaing di pasar, disebabkan karena rendahnya tingkat pengetahuan, keterampilan, dan kapabilitas terhadap penguasaan tekonologi serta akses permodalan, padahal keberadaannya memiliki posisi penting dalam perekonomian nasional. Penelitian ini bertujuan menganalisis peran modal sosial mikro dan meso serta permasalahannya terhadap kemandirian perempuan perdesaan pelaku industri rumahan emping melinjo. Penelitian dilakukan di Provinsi Banten, dengan sampel sebanyak 453 orang, terdiri dari; 154 orang di zona industri, 147 orang di zona pertanian dan 152 orang di zona pariwisata dari 6.857 orang perempuan perdesaan pelaku industri rumahan emping melinjo. Analisis data menggunakan statistik deskriptif, one way anova, dan Struktural Equation Modeling (SEM). Hasil analisis menunjukkan bahwatingkat kemandirian, tingkat kapasitas, modal sosial meso dan modal sosial mikro perempuan persdesaan berada pada kategori sedang. Model hibryd menunjukkan bahwa kemandirian perempuan perdesaan 43,0\% dipengaruhi secara langsung dan tidak langsung oleh variabel modal sosial meso, dan variabel tingkat kapasitas, sedangkan variabel modal sosial mikro berpengaruh melalui bekerjanya tingkat kapasitas. Tingkat kemandirian perempuan perdesaan ditentukan aspek pengambilan keputusan, kerjasama, kedinamisan usaha dan akses permodalan. Strategi peningkatan kemandirian dilakukan melalui penguatan modal sosial meso, terutama dukungan infrastruktur dan materi penyuluhan, yang memiliki pengaruh tidak langsung pada penguatan modal sosial mikro dan tingkat kapasitas perempuan perdesaan.
\end{abstract}

Kata kunci : Industri rumahan emping melinjo, Modal sosial mikro, Modal sosial meso, tingkat kapasitas dan tingkat kemandirian perempuan perdesaan

\section{Pendahuluan}

Industri rumahan (Home industry) kurang mampu bersaing di pasar. Hal ini karena tingkat pengetahuan, keterampilan, dan kapabilitas

${ }^{1}$ Korespondensi penulis

E-mail: khaerulsaleh63@yahoo.co.id terhadap tekonologi serta akses sumber permodalan rendah, padahal industri rumahan memiliki posisi penting dalam perekonomian nasional. (Siswanto 2009) Peran industri rumahan dalam sistim ekonomi selain menciptakan lapangan kerja juga mamapu 
meningkatkan pendapatan dan kesejahtraan rumahtangga, dalam banyak hal industri rumahan mampu berperan sebagai perekat dan stabilitas sosial terutama dalam mengurangi kesenjangan ekonomi dan sosial.

Permasalahan yang dihadapi perempuan perdesaan dalam menjalankan peran publik juga masih lemah, hal ini terlihat dari kegiatan kerjasama antar dengan individu yang dilakukannya. Terkait dengan keberlanjutan usaha, seperti pemasok bahan baku, pelanggan atau mitra usaha dan pemilik modal umumnya juga rendah (Utami\&Sumardjo, 2006). Kemandirian merupakan bentuk kejasama yang saling berketergantungan antara individu (Sumardjo,1999). Kemandirian menunjukkan keindependenan pada pihak lain, namun tetap menjalin kerjasama yang harmonis antar individu.

Kemandirian merupakan kemampuan menciptakan saling tergantungan (interdependecy) dan duduk setara dalam pola kebersamaan (partnership) dengan pihak lain (Sumardjo, 1999; Fusaeni\&Sabiti 2015), kemampuan mengatasi perbagai masalah demi mencapai tujuan tanpa tergantung atau menutup diri terhadap berbagai kemungkinan kerjasama yang saling menguntungkan, bebas menentukan nasib dan keputusannya (powerness) dalam berbagai relasi tanpa membebani pihaklain (Shatar\&Kazi,2000; World Bank, 2002).

Mu'tadin, 2002; Desmita, 2010; Wijaya, 2009:, merumuskan kemandirian sebagai sikap kebebasan (autonomy) untuk menentukan nasibnya sendiri melalui perilaku percaya diri, tidak berketergantungan, dan memiliki kebebasan dalam bertindak. Kemandirian merupakan sebuah sikap yang berangkat dari kesadaran diri untuk tidak mudah tergantung pada orang lain, namun mandiri bukan berarti tidak butuh orang lain.

Kemandirian perempuan perdesaan seyogyanya menjadi tujuan utama keberdayaan perempuan perdesaan, kemandirian perempuan perdesaan diartikan sebagai kemampuan perempuan perdesaan dalam mengembangkan jaringan antar individu dan lingkungan, sehingga terjalin ikatan kerjasama yang saling menguntungkan. Perempuanmandiri (otonom) adalah perempuan yang memiliki kebebasan untuk menentukan pilihan, memutuskan apa yang dianggapnya baik dan bermanfaat sesuai dengan kapasitas/kemampuannya (Disanayake et.al 2014). Sebaliknya kemiskinan, pengangguran dan keterbelakangan akan menjadi penghambat bahkan mempersempit ruang publik perempuan perdesaan.

Kemandirian perempuan perdesaan merupakan perpaduan antara harapan dan kepercayaan (expectatiuon and trust)(Sahyuti, 2008; Yustika, 2012),dan merupakan bagian dari multi peran perempuan, salah satunya adalahindustri rumahan emping melinjo, dan meenjadi arena (spare) bagi perempuan dalam meningkatkan kemandirian ekonomi. Kemandirian tidak dapat dipisahkan dengan perilaku ataukarakteristikperempuan, sesuai dengan sikap pribadi perempuan yang meliputi; sifatulet, sabar, tekun, memulai dari hal kecil, serta kreatif dalam memanfaatkan kesempatan dan peluang (Sitorus dan Warsito, 2013).

Modal sosial merupakan kemampuan yang muncul pada individu dari kebiasaan dan tingkat kepercayaan yang tinggi, yangmemungkinkan munculnya hubungan timbal balik dan kerjasama antar individu. Modal sosialmerupakan sarana pengembanganjaringankomunikasidankerjasamaantar individu dalam meraih dan memanfaatkan sumbersumber ekonomi(Sawitri\&Soepriadi 2014), sikap saling percaya, proaktif,kerjasama antar individu dalam komunitas, berkembang dalam masyarakat dan membentuk sistim jaringan yang melintas batas antarkeluarga, komunitas bahkan secara luas antar wilayah (Pranaji, 2006).

Modal sosial berbentuk jaringan (network) memungkinkan munculnyasumberdaya strategis dan potensial untuk dimannfaatkan responden maupun kelompok masyarakat, berupa jaringan bahan baku, jaringan pasar,jaringan informasi dan sumber permodalan (Murniarti, 2004;Maika\&Kiswanto, 2007). Karenanya ketika modal sosial (kepercayaan, norma, kerjasama dan hubugan sosial)bekerjamaka akan mendorong terciptanya kemandirian, baik kemandirian responden maupunkelompok. Namun kesenjangan juga akan terjadi bila modal sosial tidak berfungsi, bahkan menjadi penghambat atau membatasi keterlibatan peran perempuan, seperti nilai-nilai tradisi, norma maupun sikap tabu yang berlaku dalam keluarga dan masyarakat (Muin, 2013;Faturochman, 2001).

Sejalan dengan uraian yang telah diungkapkan, maka tujuan penelitian ini adalah (1) menganalsis faktor yang mempengaruhi tingkat kapasitas; (2) menganalisis faktor yang mempengaruhi tingkat kemandirian; (3) merumuskan strategi peningkatan 
kemandirian perempuan perdesaan pelaku industri rumahan emping melinjo melalui penguatan modal sosial mikro dan modal sosial meso.

\section{Metode Penelitian}

Penelitian ini dilaksanakan di Provinsi Banten, yangdibagi dalam tiga wilayah (zona) mengacu kondisi geografis wilayah,yang meliputi: zona industri, zona pertanian, dan zona pariwisata. Desain penelitian dilakukan secara kuantitatif dan kualitatif (mixed method), dengan menggunakan metode survai, studi dokumentasi dan observasi secara seimbang. Penentuan responden dilakukan secara bertingkat (multistage random sampling).

Pengumpulan data dilaksanakan dari bulan Juli sampai Desember 2015. Populasi penelitian adalah perempuan perdesaan pelaku industri rumahan emping melinjo, berjumlah 6.857 orang. Sampel yang digunakan sebanyak 453 orang, terdiri dari; 154 orang di zona industri, 147 orang di zona pertanian, dan 152 orang dari zona pariwisata. Untuk melengkapi informasi yang dibutuhkan, maka dipilih 10 orang responden kunci dari masing-masing wilayah sebagai informan.

Data bentuk skala ordinal dilakukan transformasi ke dalam data bentuk skala Interval. Proses transformasi menurut Sumardjo (1999), dilakukan untuk mendapatkan keseragaman nilai, kisaran nilai dari setiap indikator dan peubah dari nilai terendah 0 hingga nilai tertinggi 100. Rumus transformasi yang digunakan adalah sebagai berikut:

\section{Indek Transformasi Indikator $=$}

(jumlah skor dicapai-jumlah skor minimum)/(jumlah skor masimum-jumlah skor minimum) x 100

Tiap peubah diukur dengan skala yang berbeda-beda sesuai dengan definisi operasional dan indikatornya. Indikator dengan skala ordinal menggunakan skala Likert, yang menyajikan pilihan respon untuk memberikan persepsi/jawaban dengan gradasi dari paling negatif hingga paling positif dengan skor 1 untuk respon yang paling negatif dan 4 untuk respon yang paling positif.

Data yang dikumpulkan dalam penelitian ini meliputi; Karakteristik Responden $\left(\xi_{1}\right)$, Karakteristik Keluarga $\left(\xi_{2}\right)$, Kegiatan Penyuluhan $\left(\xi_{3}\right)$, Dukungan Lingkungan $\left(\xi_{4}\right)$, Modal Sosial Mikro $\left(\eta_{1}\right)$, Modal
Sosial Meso $\left(\eta_{2}\right)$, Tingkat Kapasitas $\left(\eta_{3}\right)$, dan Tingkat Kemandirian $\left(\eta_{4}\right)$, Instrumen penelitian berupa kuesioner yang disusun dalam bentuk pertanyaan atau pernyataan tertutup dan terbuka. Pengolahan dan analisis data yang digunakan adalah statistik deskriptif, one way Anova dan Structural Equation Modeling (SEM).

\section{Hasil dan Pembahasan}

\section{Deskripsi variabel terkait Peningkatan Kemandirian Perempuan Perdesaan melalui Penguatan Modal Sosial}

Secara umum variabel terkait peningkatan kemandirian perempuan perdesaan pelaku industri rumahan emping melinjo berada pada kategori sedang kecuali karakteristik responden, karakteristik keluarga dan kegiatan penyuluhan sebagaimana terlihat pada Tabel 1.Karakteristik responden berada pada kategori sangat rendah (Tabel 1), demikian pula halnya dengan karakteristik keluarga dengan kategori sangat rendah, rendahnya karakteristik responden dan karakteristik keluarga lebih dipengaruhi oleh rendahnya tingkat pendidikan yang dimiliki perempuan perdesaan pelaku industri rumahan emping melinjo dan keluarganya. Berdasarkan analisis faktor, rendahnya karakteristik responden juga dipengaruhi oleh, skala usaha, akses informasi, penguasaan bahan baku dan penguasaan teknologi, sedangkan rendahnya karakteristik keluarga dipengaruhi oleh status perkawinan, tingkat pendidikan dan usia kepala keluarga. Hasil analisis Anova diketahui bahwa karakteristik responden berbeda nyata pada masing-masing zona, sedangkan karakteristik keluarga pada zona industri berbeda nyata dengan zona pertanian dan zona pariwisata, sedangkanzona pertanian dan zona pariwisata, karakteristik keluarga tidak berbedanyata.

Variabel kegiatan penyuluhan yang diharapkan mampu meningkatkan kualitas pribadi dan keluarga perempuan perdesaan berada pada kategori rendah, kegiatan penyuluhan pada zona pariwisata dan zona pertanian sudah lebih baik dibanding zona industri, rendahnya kegiatan penyuluhan lebih dipengaruhi oleh rendahnya tingkat intensitas kegiatan penyuluhan.

Variabel dukungan lingkungan, modal sosial mikro, modal sosial meso, tingkat kapasitas dan tingkat kemandirian perempuan perdesaan berada pada kategori sedang (Tabel 1), dukungan lingkungan 
Tabel 1. Skor Rataan Variabel Terkait Kemandirian Perempuan Perdesaan

\begin{tabular}{|c|c|c|c|c|c|c|c|c|c|}
\hline \multirow{3}{*}{ Nama Variabel } & \multicolumn{6}{|c|}{ ZONA } & \multirow{2}{*}{\multicolumn{2}{|c|}{ Total }} & \multirow{3}{*}{$\begin{array}{c}\text { Hasil } \\
\text { uji t } \\
\alpha=+, \bullet\end{array}$} \\
\hline & \multicolumn{2}{|c|}{ Industri } & \multicolumn{2}{|c|}{ Pertanian } & \multicolumn{2}{|c|}{ Pariwisata } & & & \\
\hline & Mean & S dev & Mean & S dev & Mean & S dev & Mean & S dev & \\
\hline Karakteristik responden & 21,3 & 9,2 & 34,5 & 10,4 & 42,7 & 12,5 & 32,7 & 13,9 & $0,001 *$ \\
\hline Karakteritik keluarga & 33,9 & 11,5 & 38,3 & 8,9 & 37,5 & 10,8 & 36,6 & 10,6 & $0,005 *$ \\
\hline Kegiatan penyuluhan & $40,3^{\mathrm{a}}$ & 10,7 & $49,0^{b}$ & 10,3 & $49,2^{b}$ & 11,6 & 46,1 & 11,6 & 0,399 \\
\hline Dukungan lingkungan & $63,4^{\mathrm{a}}$ & 12,4 & $61,4^{\mathrm{a}}$ & 9,8 & $62,7^{\mathrm{a}}$ & 13,5 & 62,6 & 11,9 & $0,002 *$ \\
\hline Modal sosial mikro & $65,8^{a}$ & 5,5 & $74,8^{\mathrm{c}}$ & 4,1 & $72,4^{b}$ & 8,4 & 70,9 & 7,3 & $0,000 *$ \\
\hline Modal sosial meso & $61,9^{\mathrm{a}}$ & 4,5 & $63,9^{b}$ & 4,5 & $60,7^{\mathrm{a}}$ & 4,5 & 62,2 & 4,7 & 0,803 \\
\hline Tingkat kapasitas & $72,9^{a}$ & 9,2 & $70,3^{b}$ & 7,6 & $74,6^{\mathrm{a}}$ & 10,0 & 72,5 & 9,2 & $0,001 *$ \\
\hline Tingkat kemandirian & $68,3^{\mathrm{a}}$ & 11,2 & $67,8^{\mathrm{a}}$ & 7,6 & $60,1^{b}$ & 7,3 & 65,4 & 9,6 & $0,000 *$ \\
\hline
\end{tabular}

Keterangan

1) Notasi huruf (a atau b) yang sama menunjukkan tidak berbeda nyata berdasarkan uji one way Anova

2) * signifikan pada taraf nyata $\alpha=0,05$ (berdasarkan hasil uji t)

3) Skor $0-20 \quad=$ Buruk;

Skor $21-39=$ Sangat rendah;

Skor $40-60 \quad=$ Rendah;

Skor $61-79=$ sedang;

Skor $80-100=$ Tinggi

pada zona industri kondisinya lebih tinggi dibanding zona pariwisata dan pertanian, sedangkan modal sosial mikro pada zona pertanian memiliki skor lebih tinggi dibanding dengan zona pariwisata dan industri. Modal sosial meso, tingkat kapasitas dan tingkat kemandirin perempuan perdesaan di masing masing zona memiliki skor yang hampir sama dan tidak berbedanyata.

Faktor yang Mempengaruhi Kemandirian Perempuan PerdesaanPelaku Industri Rumahan Emping Melinjo

Padahipotesisawal,didugabahwakemandirian perempuan perdesaan pelaku industri rumahan emping melinjo, dipengaruhi oleh faktor modal sosial mikro ( $\eta$ 1), modal sosial meso (n2), dan tingkat kapasitas (n3). Setelah direspesifikasi model sebagaimana Gambar 1, tidak semua faktor yang diusung berpengaruh secara positif terhadap kemandirian perempuan perdesaan dalam menjalankan industri rumakan emping melinjo. Modal sosial mikro ( $n 1$ ) berpengaruh secara negatif pada tingkat kemandirian, namun memberikan pengaruh positif pada tingkat Kapasitas (Gambar 1) melalui analisis Confirmatory Faktor Analysis(CFA) diperoleh bahwa modelyang dihasilkan fit dan didukung oleh aspek-aspekprediktor yang dinyatakan valid serta dapat digunakan untuk mengukur peubah laten.

\section{a. Penguatan Modal Sosial Mikro}

Tabel 1 dan Gambar 1, menunjukkan modal sosial mikro berada pada kategori sedang, keberadaan modal sosial mikro dipengaruhi oleh karakteristik responden, modal sosial meso dan karakteristik keluarga. Karakteristik responden ditentukan oleh aspek pendidikan formal, skala usaha, akses terhadap informasi, penguasaan bahan baku dan penguasaan teknologi, karakteristik responden dapat ditingkatkan melalui Penguasaan bahan baku, penguasaan teknologi, akses informasi dan penguatan skala usaha, yang pengaruhnya terhadap karakteristik responden rendah, karena kegiatan industri rumahan emping melinjo yang dilakukan perempuan perdesaan di Provinsi Banten cenderung dilakukan secara turun temurun dan tidak kapabel terhadap teknologi.

Karakteristik keluarga perempuan perdesaan pelaku industri rumahan emping melinjo, berpengaruh pada penguatan modal sosial mikro (Gambar 1). Pengaruh yang diberikan karaktristik keluarga berarah negatif, hal ini menunjukkan bahwa struktur keluarga yang dibangun masyarakat perdesaan Banten baik secara sosial maupn budaya masih lekat dengan budaya patriarki, dimana pandangan subordinasi bagi perempuan masih mewarnai kehidupan keluarga dan masyarakat baik dalam kancah ekonomi maupun sosial 
politik. Kuatnya budaya patriaki, pada masyarakat perdesaan menimbulkan prilaku inword looking, yakni perilaku tertutup dan penuh dengan kecurigaan pada perempuan.

Faktor lain yang mempengaruhi penguatan modal sosial mikro adalah modal sosial meso, keberadaan modal sosial meso dalam masyarakat perdesaan berperan sebagai penghubung sosial (social linking), aktivitas domestik maupun aktivitas pablik yang dijalankan perempuan perdesaan merupakan proses interaksi sosial atau kerjasama yang dibangun perempuan dengan tujuan meningkatkan pendapata dan kesejahtraan keluarga. Kepercayaan, tindakan proaktif dan norma sosial merupakan unsur modal sosial meso perempuan perdesaan pelaku industri rumahan emping melinjo, tingginya tingkat kepercayaan dan tindakan proaktif sebagai bentuk diterimanya perempuan dalam ruang publik.

Kepercayaan dan tindakan proaktifmerupakan sikap saling membantu, saling memberi dan menerima, antar responden dalam masyarakat, dan menjadi roh dari modal sosial, (Munandar\&Homzah, 2005). Kepercayaan dan tindakan proaktif yang melekat dalam diri perempuan perdesaan, menunjukkan bahwa modal sosial yang berkembang pada perempuan perdesaan telah membuka ruang perempuan untuk berinteraksi secara luas dan terbuka baik melalui jaringan pasar, informasi maupun jaringan komunikasi yang dibutuhkan dalam pengembangan industri rumahan emping melinjo.

\section{b. Penguatan Modal Sosial Meso.}

Tabel 1 terlihat bahwa modal sosial meso perempuan perdesaan pelaku industri rumahan emping melinjo berada pada kategori sedang. Secara struktural modal sosial meso (komunitas) dipengaruhi oleh faktor dukungan lingkungan dan kegiatan penyuluhan (Gambar 1). Dukungan lingkungan dibentuk melalui aspek ketersediaan infrastruktur, dukungan sosial ekonomi, dan dukungan lingkungan keluarga. Modal sosial meso berperan sebagai penghubung sosial (sociallinking) dan perekat sosial (social glue) bagi pengembangan keberlanjutan usaha perempuan perdesaan baik dengan pemasok bahan baku, pelanggan atau mitra dan pemilik modal.

Interaksisosial(socialinteractions)perempuan perdesaan yang dilakukan melalui apek dukungan kelembagaan sosial ekonomi (KUB, Koperasi, arisan kegiatan keagamaan) dan dukungan keluarga (keluarga

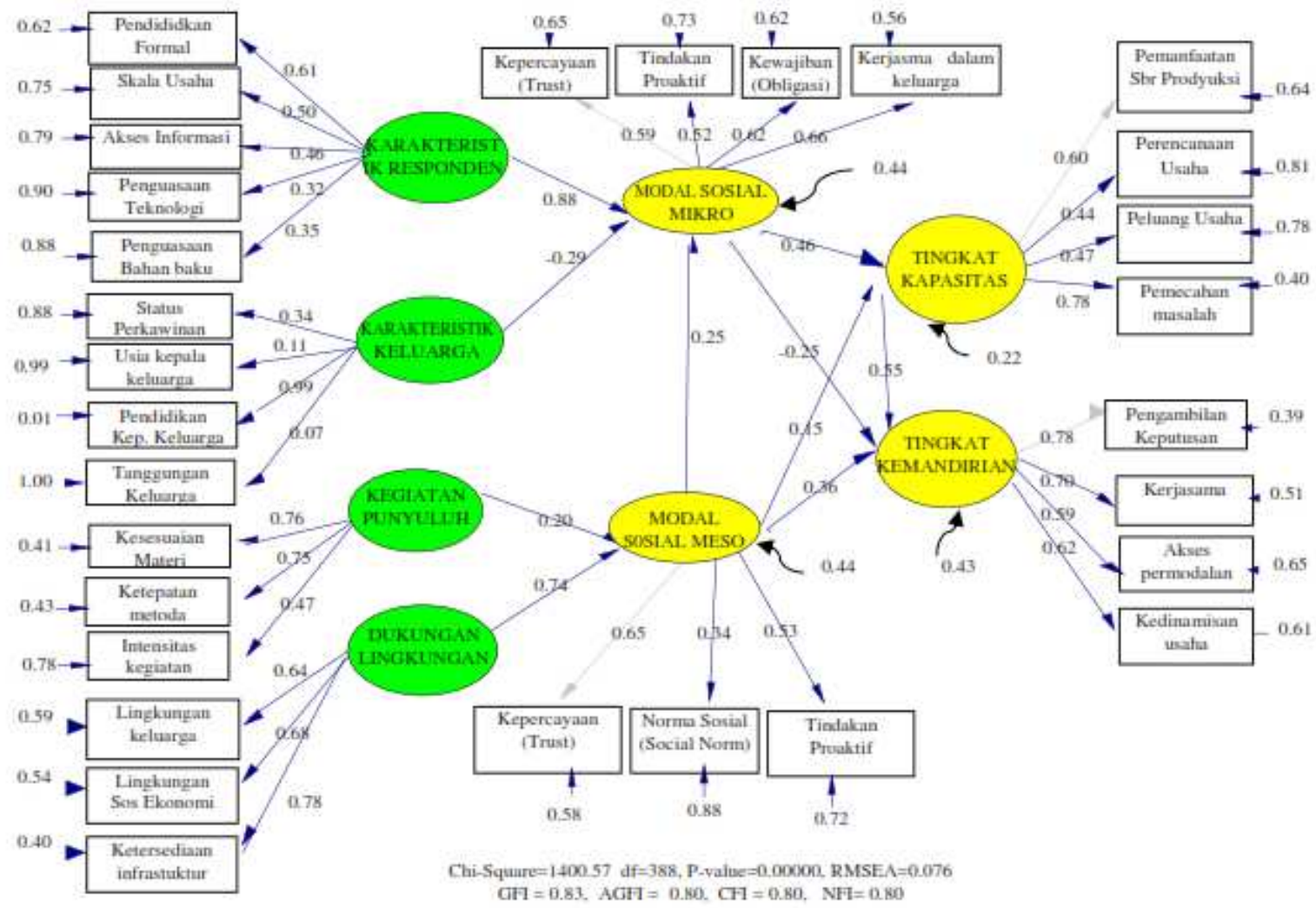

Gambar 1. Model hibryd Kemandirian Perempuan Perdesaan Pelaku Industri Rumahan Emping Melinjo melalui penguatan Modal sosial 
inti dan keluaaga dekat) menghasilkan sistim jaringan yang melintas batas dengan radius yang lebih luas baik di tingkat lingkungan, desa bahkan tingkat Kecamatan dan Kabupaten (Pranaji 2006). Karenanya modal sosial meso bukan sebatas penghubung dan perkat sosial bahkan lebih luas lagi sebgai jembatan (bridging) antara kepentingan individu dengan komunitas.

Faktor lain yang mempengaruhi keberadan modal sosial meso adalah kegiatan penyuluhan, kegiatan penyuluhan melalui aspekmetoda, dan materi penyuluhan, sebagai sarana meningkatkan kemampuan dan keterampilan perempuan dalam menjalankan usaha industri rumahan emping melinjo. Rendahnya tingkat intensitas kegiatan penyuluhan selain disebabkan karena keterbatasan jumlah personal penyuluh, juga usaha industri rumahan umumnya belum menjadi starategi unggulan pembangunan ekonomi.

Pengembangan modal sosial melalui kegiatan penyuluhan salah satunya adalah mengintroduksikan nilai-nilai sosial yang berkembang dalam masyarakat seperti kepercayaan (trustworthy), kerjasama yang saling menguntungkan dan hubungan timbal balik antar Individu dalam komunitas, yang teraktualisaikan melalui pengembangan jaringan sosial sebagai agregat potensial dan aktual, untuk terwujudnya keberlangsungan usaha yang saling menguntungkan (Syahyuti, 2008; Yustika, 2012), dalam dalam prakteknya pengembangan modal sosial melalui kegiatan penyuluhan mencakup aktivitas; (1) kemampuan membangun kelambagaan (institutions building), (2) kemampuan berpartisipasi secara adil dan setara, dan (3) sikap saling percaya, saling mendukung, saling peduli (solidarity) dan saling memperkuat antar pihak yang terlibat dalam jaringan (Sumardjo, 2012).

\section{Faktor-faktor yang Mempengaruhi Tingkat Kapasitas Perempuan Perdesaan}

Gambar 1, menunjukkan bahwa tingkat kapasitas perempuan perdesaan dipengaruhi secara langsung oleh faktor modal sosial mikro (keluarga) dan modal sosial (komunitas). Karakteristik responden dan karakteristik keluarga tidak berpengaruh secara langsung pada tingkat kapasitas melainkan melalui modal sosial mikro (Gambar 1), demikian pula pada dukungan lingkungan dan kegiatan penyuluhan berpengaruh pada tingkat kapsitas melalui modal sosial meso. Artinya bahwa semakin tinggi modal sosial (mikro dan meso) yang dimiliki perempuan perdesaan maka tingkat kapsitas perempuan perdesaan pelaku industri rumahan emping melinjo semakin tinggi.

Tabel 1, menunjukkan bahwa tingkat kapasitas perempuan perdesaan berada pada katagori sedang. Tingkat kapasitas perempuan perdesaanpelaku industri rumahan emping melinjo di Provinsi Banten sebagaimana Gambar 1, diukur melalui aspek kemampuan dalam mecahkan masalah, kemampuan memanfaatkan sumber produksi, pemanfaatan peluang usaha dan perencanaan usaha.

Modal sosial mikroberpengaruh sebesar 0,46 atau 21,15\% melalui aspek kerjasama dalam keluarga, kewajiban, kepercayaan dan tindakan proaktif terhadap tingkat kapasitas perempuan perdesaan pelaku industri rumahan emping melinjo, sedangkan modal sosial meso berpengaruh sebesar 0,15 atau 2,25\% melalui aspek kepercayaan, tindakan proaktif dan norma sosial.

Tingkat kapasitas yang dimiliki perempuan perdesaan sebagai bentuk kemampuan perempuan perdesaan dalam menjalankan usaha industri rumahan emping melinjo, akan semakin efisienapa bila didukung dengan jaringan sosial (sosial networking) yang merupakan bagian dari kekuatan modal sosial. Modal sosial menuntut partisipasi dalam jaringan, trust, norma sosial, sifat keumuman pemilikan (the common), dan sikap komunitas yang proaktif (Syahyuti, 2008).

Kapasitas hanya akan tercipta bila ada sikap timbal balik (resiprositas) yang tinggi antara individu. Artinya, kapasitas bukan semata-mata hanya sebagai suatu kemampuan dalam melakukan suatu pertimbangan dan juga perhitungan bisnis melainkan kombinasi antara sifat kepentingan pribadi jangka pendek dengan harapan keuntungan dalam jangka panjang sebagai dukungan keberlanjutan usaha. Karenanya peran modal sosial mampu mengikatkerjasama dalam keluarga, memberikan kepercayaan, dan menjalankan tindakan proaktif, bukan semata menjadi perekat sosial (social glue) dan dukungan sosial akan tetapi menjadi ekspektasi dan altruism antara Individu dalam keluarga dan komunitas.

\section{Faktor-faktor yang Mempengaruhi Tingkat Kemandirian Perempuan Perdesaan Pelaku Industri Rumahan Emping Melinjo di Provinsi Banten}

Kemandirian perempuan perdesaan berada pada kelompok sedang, dan dipengaruhi secara 
langsung dan positif oleh tingkat kapasitas (n3), dan modal sosial meso (n2), sedangkan modal sosial mikro (n1) memiliki pengaruh negatif, sebagaimana Gambar 1. Meningkatnya kemandirian perempuan perdesaan pelaku industri rumahan emping melinjo, sejalan dengan tingginya tingkat kapasitas dan modal sosial. Keberadaan modal sosial baik tingkat mikro maupun tingkat meso secara langsung maupun tidak langsung berpengeruh pada peningkatkan kemandirian perempuan perdesaan pelaku industri rumahan emping melinjo.

Pengaruh langsung modal sosial mikro (keluarga) terhadap tingkat kemandirian lebih diwarnai oleh budaya patriarkhi, yang menempatkan perempuan tidak banyak memiliki pilihan. Rendahnya tingkat kemandirian perempuan karena rendanya relasi yang terjadi dalam keluarga di mana karakter perempuan disandingkan dengan karakter laki laki, menjadikan perempuan sulit lepas dari dominasi laki-laki, seperti dalam melakukan kerjasama, dan mengembangkan jaringan pasar.kerjasama dalam keluarga kewajiban dan kepercayaan, untuk meningkatkan kemandirian maka sumberdaya keluarga harus dimiliki dan dikuasai sepenuhnya oleh perempuan (Prakash 2002).

Keberadaan modal sosial meso dalam meningkatkan kemandirian perempuan perdesaan dalam menjalankan industri rumahan emping melinjo, melalui perluasan jaringan dengan memanfaatkan potensi dan dukungan lingkungan seperti infrastruktur kelembagaan sosial ekonomi, serta memaksimalkan peran dan dukungan keluarga (keluarga inti dan keluarga dekat).

Berdasarkan Gambar 1 terlihat bahwa tingkat kemandirian perempuan perdesaan pelaku industri rumahan emping melinjo ditentukan oleh aspek pengambilan keputusan, kerjasama dengan pihak luar, kedinamisan usaha dan akses permodalan, rendahnya akses permodalan terhadap tingkat kemandirian, bila ditelusuri lebih lanjut disebabkan, selain oleh faktor internal juga oleh faktor eksternal terutama yang terkait administrasi yang dibutuhkan kreditor (lembaga perbankan).

Dari uraian tersebut didapat tingkat kemandirian perempuan perdesaan pelaku industri rumahan emping melinjo sebagaimana Gambar 1, secara simultan dapat dirumuskan sebuah model struktural sebagai berikut; $\boldsymbol{\eta}_{4}=\mathbf{- 0 , 2 5} \boldsymbol{\eta}_{1}+\mathbf{0 , 3 6} \boldsymbol{\eta}_{2}+$ $\mathbf{0 , 5 5} \eta_{\mathbf{3}}$ dengan $R^{2}=43 \%$. Nilai $R^{2}$ menunjukkan bahwa 43 \%tingkat kemandirian pelaku industri rumahan emping melinjo Provinsi Banten dipengaruhi oleh bekerjanya modal sosial mikro, modal sosial meso dan kapasitas sedangkan sisanya $57 \%$ dipengaruhi oleh faktor lain di luar model.

\section{Strategi Penguatan Modal Sosial Perempuan Perdesaan dalam Peningkatan Kemandirian Perempuan Perdesaan pelaku industri rumahan emping melinjo di Propinsi Banten}

Model hybridyangdiperoleh darianalisis SEM menunjukkan nilai pengaruh, nilai validitas, dan nilai reliabilitas signifikan antara variabel laten endogen dan variabel laten eksogen dalam peningkatan kemandirian perempuan perdesaan pelaku industri rumahan emping melinjo, hasil analisis SEM (Gambar1) memberikan informasi bahwa variabel yang mempengaruhi kemandirian perempuan perdesaan pelaku industri rumahan emping melinjodi Provinsi Banten adalah kapasitas dan modal sosial meso.

Strategi peningkatan kemandirian perempuan perdesaan pelaku industri rumahan emping melinjo melalui penguatan modal sosial di Provinsi Banten merujuk Gambar1, dilakukan melalui tiga pendekatan/ strategi. Pertama, peningkatan kemandirian perempuan dilakukan dengan meningkatkan modal sosial meso dan tingkat kapasitas. Modal sosial meso berpengaruh pada penguatan pada modal sosial mikro, dan tingkat kapasitas, modal sosial meso selain dipengaruhi oleh dukungan lingkungan juga dengan memaksimalkan peran penyuluhan yang meliputi;(1) memfasilitasi kreativitas perempuan perdesaan; (2) mendorong pemanfaatan teknologi dan inovasi produk sesuai dukungan lingkungan; (3) peningkatan manajemen pengetahuan, sikap dan keterampilan (pencarian dan penyimpanan bahan baku, pengemasan dan penyampaian); dan (4) mengadakan pelatihan dan fasilitasi akses informasi, sehingga terjadi perubahan pola pikir (mindset) perempuan dan keluarga menjadi lebih terbuka.

Kedua peningkatan kapasitas dilakukan dengan menguatkan modal sosial meso melalui peningkatankualitas kelembagaan, dan peran penyuluh. peningkatan kualitas kelembagaan agar usaha yang diajalankan perempuan menjadi effisien meliputi keterlibatan perempuan dalam KUB Koperasi maupun paguyuban. penguatan kelambagaan, meliputi; (1) penguatan kelembagaan yang berkeadilan dan dapat dipercaya (trustworthy); (2) keterjaminan iklim usaha; 
(3) pembenahan struktur dan jaringan pasar; serta (4) ketersediaan sumber permodalan yang murah dan mudah. peningkatan kegiatan penyuluhan secara intesif dan berkesinambungan, melalui pendampingan, fasilitasi maupun studi banding (karyawisata) dengan melibatkan anggota keluarga.

Ketiga, rendahnya tingkat pendidikan dan skala usaha mempengaruhi keberadaan modal sosial mikro penguatan modal sosial mikro (Keluarga) dibangun melalui berbagai upaya perbaikan karakter perempuan pelaku industri rumahan melalui; (1) upaya membuka diri terhadap segala informasi; (2) peningkatan skala/kapasitas; (3) melakukan reposisi/ sikap dari inward looking ke outward looking; (4) upaya menjaga keberlangsungan usaha; (5) selalu berusaha membangun jejaring

Tingkat kemandirian akan berdampak (outcame) pada keberlanjutan usaha kesejahteraan keluarga perempuan, berupa (1) kepastian dan keberlangsungan berusaha (sustainable lifelihood) yang menyangkut unsur kepastian pasar, ketersediaan sumberdaya dan dukungan lingkungan, serta optimalisasi peran kelembagaan sosial ekonomi; (2) Peningkatan Pendapatan keluarga (income generating family) ditandai dengan; meningkatnya penghargaan diri (self-esteem) perempuan, dapat merasakan tingkat hidup yang lebih baik, memiliki kesempatan untuk membuat akumulasi asset, (3) peningkatan kesejahteraan keluarga (wellbeing of family) ditandai dengan; terpenuhinya kebutuhan hidup dasar (ekonomi, pendidikan dan liburan), budaya menabung meningkat, dan berkembangnya perilaku berbagi (menolong).

\section{Kesimpulan}

Tingkat kemandirian perempuan perdesaan pelaku industri rumahan emping melinjo termasuk kategori sedang, hal ini terutama dipengaruhi oleh modal sosial meso dan tingkat kapasitas, yang masingmasing berada padakondisi sedang, modal sosial mikro hanya akan berpengaruh terhadap tingkat kemandirian perempuan perdesaan apabila berdampak pada meningkatnya kapasitas perempuan perdesaan pelaku industri rumahan emping melinjo.

Tingkat kapasitas perempuan perdesaan terutama disebabkan oleh keberadaan modal sosialmikro serta modal sosial meso, modal sosial meso berampak positif terhadap modal sosial mikro, sehingga upaya menguatkan modal sosial meso selain berdampak pada tingkat kapasitas perempuan perdesaan juga kemandirian perempuan dalam menjalankan usaha, terutama apabila modal sosial meso mampu meningkatkan peran modal sosial mikro (keluarga) terutama pada aspek pendidikan formal dan skala usaha.

Strategi untuk meningkatkan kemandirian perempuan perdesaan pelaku industri rumahan emping melinjodilakukan melalui perbaikan karakteristik responden terutama terutama sapek pengausaan bahanbaku, pengausaan teknologi, skala usaha dan akses informasi usaha (pasar, harga, teknologi/ inovasi) dan penguasaan bahan baku, sedangkan penguatan modal sosial mikro dilakukan melalui aspek kerjasama dalam keluarga, kewajiban dalam keluarga, dan kepercayaan. Modal sosial meso (komunitas) memeberikan konstribusi pada kemandirian perempuan melakui aspek dukungan infrastruktur, dukungan kelembagaan sosisl ekonomi dan dukungan lingkungan keluarga serta ditunjang dengan adanya kegiatan penyuluhan yang memiliki kesesuaian dengan kebutuhan perempuan perdesaan baik metoda maupun materi yang disamapaikannya. Kemandirian perempuan pedesaan dapat dilakukan melalui peningkatan kapasitas terutama melalaui aspek kemampuan dalam memecahkan masalah dan kemampuan memanfaatkan sumber produksi.

\section{Daftar Pustaka}

Desmita. 2010. Pshikologi Perkembangan Peserta Didik. Bandung (ID): PT Remaja Rosdakarya.

Disanayake CAK, De Silva J.A.S, Wasala W.M.C.B. and Thilakarathne B.M.K.S. 2014. Empowermen of women throught Self reliance approach in the Rice Processing Vilage Programme. Jopurnal Tropikal Agrikultural Reseach, 25(3) : 307-315.

Faturochman M.A. 2001. Revitalisasi peran keluarga. Yogyakarta (ID): Buletin Psikologi Universitas Gajah Mada : 39-37.

Fusaeni K \& Sabiti Ishmael, K. 2015. Women's Autonomy in Ghana: Does Religion Matter ?. African Population Studies, 29(2) : 1831-1842.

Jejeebhoy J Shireen, Satar A. 2001. Women's autonomi in India and Pakistan; the influence of religion and region. Populations and Development review, 27(4) : 687-712.

Maika A, Kiswanto E. 2007. Pemberdayaan Perempuan Miskin Pada Usaha Kecil di Perdesaan 
Melalui Layanan Lembaga Keuangan Mikro (Grameen Bank) Center for Population and Policy Studies Gadjah Mada University S.344. Makalah disampaikan dalam seminar Bulanan Pusat Studi Kependudukan dan Kebijakan (PSKK) UGM, Kamis 26 April 2007.

Mu'tadin Z. 2002. Kemandirian sebagai kebutuhan psikologis pada remaja. [Internet] http//www. damandiri.or.id.php?id=340.htm. diunduh januari 2014

Muin, Sri Adrianti. 2013. Kajian Kemampuan Usaha dan Modal Sosial Serta Implikasinya Terhadap Kinerja Usaha Kecil Sektor Industri Di Sulawesi Selatan Assets Volume 3 Nomor 1 Tahun 2013 [Internet] http://www.uin-alauddin.ac.id/ download-4-SRI\%20ADRIANTI.pdf diakses tanggal 16 Sept 2014.

Munandar S, Homzah S. 2005. Pengembangan (Modifikasi) Teori Modal Sosial dan Aplikasinya Yang Berbasis Masyarakat Petani Peternak (Studi Kasus Pendekatan Sosiologis Pada Kelompok dan Organisasi Usaha Tani Ternak Sapi Perah Di Kecamatan Pangalengan Kabupaten Bandung). Bandung (ID): Laboratorium Sosiologi dan Penyuluhan Fakultas Peternakan Universitas Padjadjaran

Murniati P. A Nunuk. 2004. Getar Gender. Perempuan Indonesia dan Prespektif Agama, Budaya dan Keluarga. Jakarta (ID): Indonesiatera.

Nawawi H, Martini M. 1994. Manusia Berkualitas. Yogyakarta (ID): Gajah Mada University Press.

Prakash A. 2002. Green marketing, public policy and managerial strategiesBusiness Strategy and the Environment; Sep/Oct 2002; 11, 5; ABI/INFORM Global.

Pranadji T. 2006. Penguatan Modal Sosial untuk Pemberdayaan Masyarakat Perdesaan dalam Mengelola Agro Ekosistem Lahan Kering (ALK), Kasus Di Desa-Desa Ex Proyek Bangun Desa Kabupaten Gunung Kidul dan Kabupaten Boyolali. Jurnal Agro Ekonomi , 24(2) :178-206.

Satar, Ayesa Z, Syahnaz K. 2000. Women's Autonomy in the Context of Rural Pakistan. The Pakistan Developmen review. 39(2) : 89-110.

Sawitri D, Soepriadi F. 2014. Modal Sosial Petani dan perkembangan Industrialisasi di Desa Sentra Pertanian Kabupaten Subang dan Karawang. Jurnal Perencanaan Wilayah dan Kota, 25(1) : 1737.
Setiawan I. 2015. Perkembangan Kemandirian Pelaku Brain Gain Sebagai Alternatif Inovasi Regenerasi Pelaku Agribisnis di Dataran Tinggi Jawa Barat Disertasi. Bogor (ID): Program Pascasarjana Institut Pertanian Bogor.

Siswanto A, Victorianus. 2009. Studi peran perempuan dalam pengembangan usaha kecil menengah melalui teknologi informasi di kota pekalongan. Dinamika Informatika, 1(1) : 70-77.

Sitorus L, Saulina I, Warsito HW. 2013. Perbedaan Tingkat Kemandirian dan Penyesuaian Diri Mahasiswa Perantauan Suku Batak Ditinjau Dari Jenis Kelamin. Jurnal Chracter Universitas Negri Surabaya, 1(2).

Steinberg L. 2002. Adolescence. Sixth edition. New York (US): McGraw-Hill.

Sumardjo. 1999. Transformasi Model Penyuluhan Pertanian Menuju Pengembangan Kemandirian Petani (Kasus di Provinsi Jawa Barat). Disertasi. Bogor (ID): Program Pascasarjana Institut Pertanian Bogor.

Sumardjo. 2012. Kelembagaan dan Kompetensi Penyuluh dalam Pemberdayaan Masyarakat. Makalah disampaikan dalam forum pertemuan kelembagaan pembangunan di Daerah, di Padang Sumatera Barat, tanggal 21 April 2012.

Syahyuti. 2008. Peran Modal Sosial (Social Capital) dalam Perdagangan Hasil Pertanian. Forum Agro Ekonomi, 26(1) : 32-43.

Utami HN, Sumardjo. 2006. Faktor faktor yang berhubungan dengan kemandirian pengrajin Kulit di kabupaten Sidoarjo dan Magetan Jawa Timur. Bogor (ID): Jurnal Penyuluhan, 2(4).

Wijaya M. 2009. Kemandirian Perempuan dalam Pengembangan Off Farm Activity: Industri Kerajinan Batik Tulis. M'POWER, 9(9) : 14-23.

World Bank. 2002. Engendering Development: Through Gender Equality in Rights, Resources, and Voice. New York and Oxford (US): Oxford University Press; Washington, D.C.: World Bank. Yustika, EA. 2012. Ekonomi Kelembagaan, paradigma, Teori dan kebijakan. Jakarta (ID): Penerbit Erlangga. 